\title{
Spatially explicit estimates of stock sizes, structure and biomass of herring and blue whiting, and catch data of bluefin tuna
}

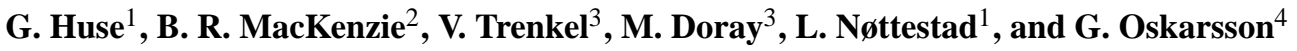 \\ ${ }^{1}$ Institute of Marine Research, Box 1870 Nordnes, 5817 Bergen, Norway \\ ${ }^{2}$ Centers for Macroecology, Evolution and Climate, and Ocean Life, National Institute for Aquatic Resources \\ (DTU Aqua), Technical University of Denmark, 2920 Charlottenlund, Denmark \\ ${ }^{3}$ Ifremer, rue de l'île d'Yeu, BP 21005, 44311 Nantes CEDEX 3, France \\ ${ }^{4}$ Marine Research Institute, Skulagata 4, 121 Reykjavik, Iceland
}

Correspondence to: G. Huse (geir.huse@imr.no)

Received: 4 February 2014 - Published in Earth Syst. Sci. Data Discuss.: 31 July 2014

Revised: 4 March 2015 - Accepted: 17 March 2015 - Published: 30 April 2015

\begin{abstract}
The North Atlantic is a productive marine region which has supported important commercial fisheries for centuries. Many of these fisheries have exploited the pelagic species, including herring, blue whiting and tuna. Here we present data on the distribution of herring and blue whiting based on the international ecosystem survey in the Nordic Seas (IESNS), the bottom trawl survey in the Bay of Biscay and Celtic Sea (EVHOE) and the pelagic survey in the Bay of Biscay (PELGAS). We also present catch data on bluefin tuna, which has been depleted for decades but historically used to be a key predator on the other pelagic stocks during summer. The results show that there were substantial changes in the herring and blue whiting distribution during the 1990s and early 2000s. The earliest bluefin tuna catches noted were in 1907. The catches in the Norwegian Sea area peaked in the 1950s and there have been very small catches since the 1980s. The reported catches in the Mediterranean, on the other hand, peaked in the late 1990s and subsequently had a strong reduction.
\end{abstract}

\section{Data sources}

EURO-BASIN WP5: T1.3.6 and T1.3.8 (D1.6 and D1.8); this compilation includes data from acoustics, trawl surveys and commercial catches.

\section{Referenced data sets}

Norwegian spring spawning herring:

- http://doi.pangaea.de/10.1594/PANGAEA.819799 (biomass data IESNS survey, 2012)

- http://doi.pangaea.de/10.1594/PANGAEA.827197 (biomass data IESNS survey, 2011)

- http://doi.pangaea.de/10.1594/PANGAEA.827196 (biomass data IESNS survey, 2010)
- http://doi.pangaea.de/10.1594/PANGAEA.827221 (biomass data IESNS survey, 2009)

- http://doi.pangaea.de/10.1594/PANGAEA.827194 (biomass data IESNS survey, 2008)

- http://doi.pangaea.de/10.1594/PANGAEA.827193 (biomass data IESNS survey, 2007)

- http://doi.pangaea.de/10.1594/PANGAEA.827192 (biomass data IESNS survey, 2006)

- http://doi.pangaea.de/10.1594/PANGAEA.827191 (biomass data IESNS survey, 2005)

- http://doi.pangaea.de/10.1594/PANGAEA.827190 (biomass data IESNS survey, 2004) 
Blue whiting:

- http://doi.pangaea.de/10.1594/PANGAEA.819117 (acoustic NASC values for PELGAS survey, 20002012)

- http://doi.pangaea.de/10.1594/PANGAEA.817175 (catches from EVHOE survey, 1997-2011)

- http://doi.pangaea.de/10.1594/PANGAEA.827380 (biomass data IESNS survey, 2012)

- http://doi.pangaea.de/10.1594/PANGAEA.827379 (biomass data IESNS survey, 2011)

- http://doi.pangaea.de/10.1594/PANGAEA.827378 (biomass data IESNS survey, 2010)

- http://doi.pangaea.de/10.1594/PANGAEA.827377 (biomass data IESNS survey, 2009)

- http://doi.pangaea.de/10.1594/PANGAEA.827376 (biomass data IESNS survey, 2008)

- http://doi.pangaea.de/10.1594/PANGAEA.827375 (biomass data IESNS survey, 2007)

- http://doi.pangaea.de/10.1594/PANGAEA.827374 (biomass data IESNS survey, 2006)

- http://doi.pangaea.de/10.1594/PANGAEA.827373 (biomass data IESNS survey, 2005)

- http://doi.pangaea.de/10.1594/PANGAEA.827372 (biomass data IESNS survey, 2004)

Bluefin tuna:

- http://doi.pangaea.de/10.1594/PANGAEA.828297 (catch data for 1950-2010)

- http://doi.pangaea.de/10.1594/PANGAEA.828295 (catch data for 1906-1949)

\section{Introduction}

\subsection{Key pelagic fish stocks in the northeastern Atlantic}

The North Atlantic is a productive marine region which has supported important commercial fisheries for centuries. Many of these fisheries have exploited the pelagic (mainly open-water, surface-living) species, such as herring ( $\mathrm{Clu}$ pea harengus Linnaeus 1758) and blue whiting (Micromesistius poutassou Risso 1826). These species are primarily, though not exclusively, zooplanktivores (Fridriksson, 1944; Prokopchuk and Sentyabov, 2006; Pinnegar et al., 2015) and thus are important links in the food web between zooplankton and piscivores (e.g. cod, seals, whales, seabirds). The biomasses of herring and blue whiting, and a few other pelagic fish species (e.g. mackerel, Scomber scombrus Linnaeus 1758), are so high that they attract many seasonal migrants to the region. Hence, upper-trophic-level predators such as bluefin tuna (Thunnus thynnus Linnaeus 1758) and some species of marine mammals and seabirds have evolved migratory behaviours to inhabit this region for feeding in the summer months (Mather et al., 1995). Fisheries therefore must be conducted in ways that are sustainable not only for the fishing industry but also for the targeted fish species, other species in the food web that depend on them for food, and more generally for maintaining healthy, resilient ecosystems.

Maintaining sustainable populations and ecosystems generally requires direct monitoring of population status and their fisheries (Hilborn and Branch, 2013; Pauly, 2013). Such data can provide a basis for fisheries management decisions (e.g. quotas). Two of the most important types of monitoring information are (1) research vessel surveys of fish abundance and distribution and (2) records of commercial catches of targeted and bycatch species. These data can reveal when and where the fish were located as well as when and where they were being exploited. The data can then be compared in time and space and used in models with other data (e.g. fishing effort, fish sizes and ages) to estimate whether populations are stable, declining or increasing. When provided with this knowledge, fishery managers can make decisions on future quotas and identify possible conservation actions (e.g. minimum size limits, implementation of closed areas or seasons for fishing) that can reduce the risk of stock collapses and local extinctions.

\subsection{Norwegian spring-spawning (NSS) herring}

The NSS stock migrates widely over large areas in the northeastern Atlantic, including the Barents Sea, Norwegian Sea and Icelandic Sea (Devold, 1963; Dragesund, 1970; Røttingen, 1990; Dragesund et al., 1997; Fernö et al., 1998; Jakobsson and Østvedt, 1999; Holst et al., 2002). The life cycle of the NSS herring presently includes spawning along the Norwegian coast in late winter, nursery areas along the coast and in the Barents Sea, feeding areas in the Norwegian Sea and overwintering outside northern Norway (Fig. 1). During the last decades the stock has changed its distribution and migration pattern substantially with regards to spawning, feeding and overwintering areas (Fig. 1). Between 1968 and 1977 the NSS herring spawning stock biomass (SSB) declined to less than $0.2 \mathrm{Mt}$, with a minimum occurring in 1971 (Toresen and Østvedt, 2000). Fishing mortality, $F$, was as high as 1.5 during the pre-collapse period (Dragesund et al., 1980), but since 1994 it has ranged from 0.18 to 0.24 in accordance with the long-term management plan (ICES, 2013). The spawning stock was rebuilt during the 1980s and 1990s and remained at a fairly high level from 1988 to 1999 , followed by a decline from 1999 to 2002. From 2003 to 2009 the SSB increased, followed by a more rapid decrease from 2009 to 2013 due to 

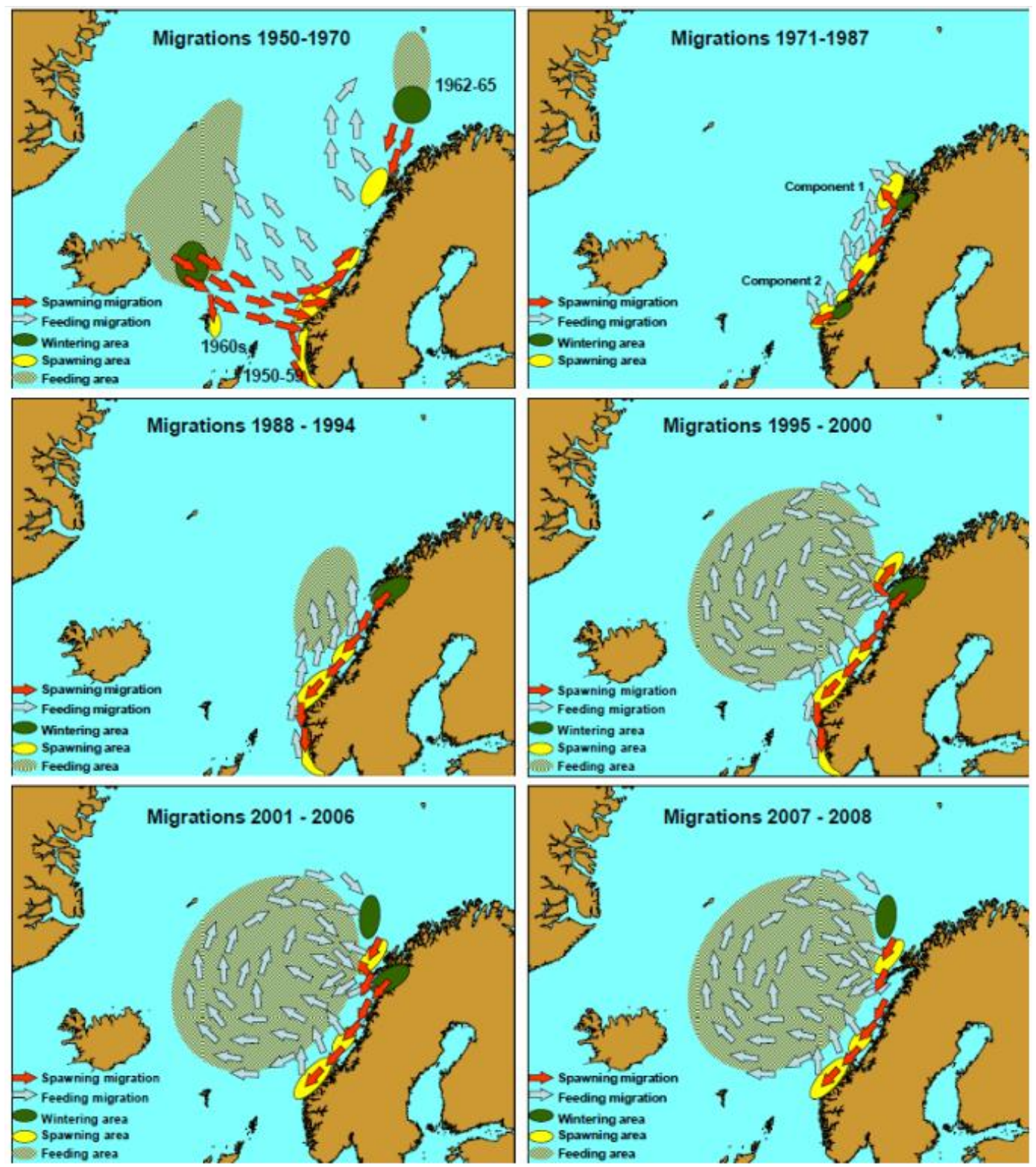

Figure 1. Schematic overview of historical changes in the adult NSS herring seasonal migration pattern. Reproduced with permission from Slotte and Skaret (2010).

a lack of strong recruitment since 2004 (ICES, 2013). In the last two decades the NSS herring fishery has been the largest herring fishery in the Atlantic, with landings ranging from 0.969 to $1.687 \mathrm{Mt}$ between 2005 and 2013 (ICES, 2013), not so far from the pre-collapse catches that approached $2 \mathrm{Mt}$ in 1968 (Toresen and Østvedt, 2000). Usually, the NSS herring fishery takes place in the Norwegian Sea during the summer and autumn and in the Norwegian coastal areas during the autumn and winter, including the spawning period (ICES, 2013).

\subsection{Blue whiting}

Blue whiting is widely distributed over the northeastern Atlantic with the dominant spawning area situated to the west of the British Isles. It has a major feeding migration and summer distribution north all the way up to Svalbard and into the Barents Sea and southward down to the Bay of Biscay and the Iberian coast (Fig. 2) (Monstad, 2004). Blue whiting SSB has been fluctuating around $2 \mathrm{Mt}$ from 1981 to 1997. From 1997 to 2004 the SSB increased rapidly to about $7 \mathrm{Mt}$, followed by a similarly rapid decline from 2005 until 2011 and a subsequent increase to an SSB of 5.5 Mt in 2013 (ICES, 2013). 


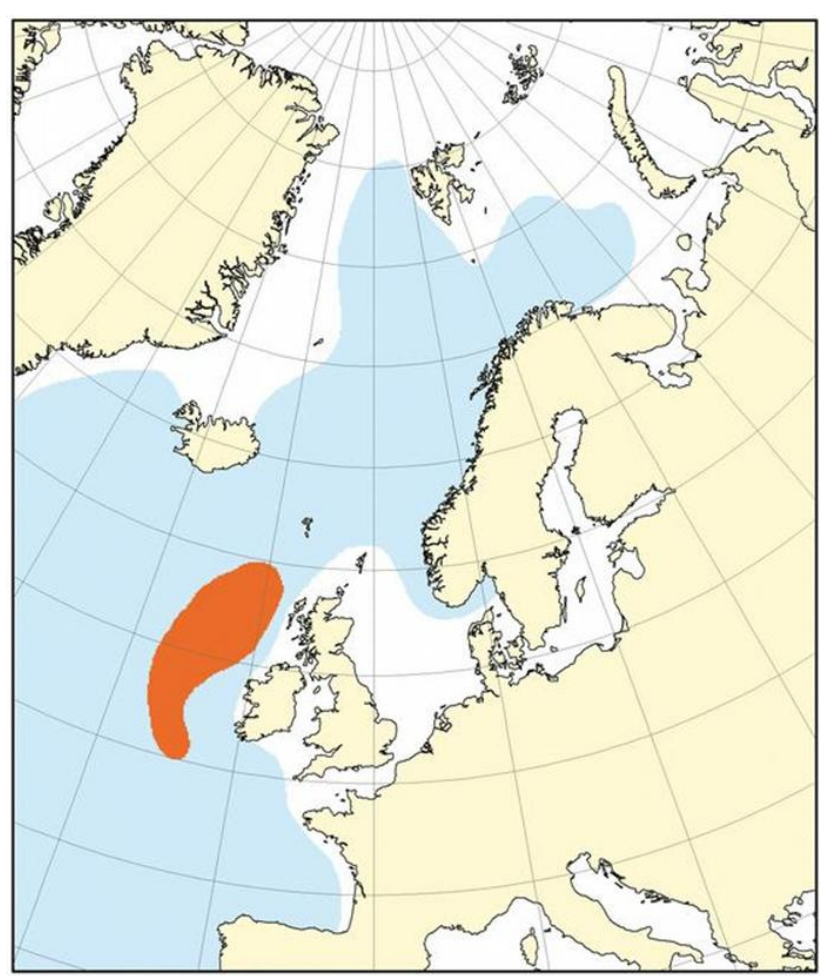

Figure 2. Schematic overview of overall distribution (blue) and spawning area (orange) for blue whiting.

The fishery for blue whiting has displayed a dramatic "boom and bust" dynamic over the past two decades (ICES, 2013). The modern commercial fishery of this stock began in the late 1970s and early 1980s. Landings during the 1980s and early 1990s were typically between 0.5 and $1 \mathrm{Mt}$. However, the late 1990s and early 2000s saw a succession of extremely strong year classes, starting with the 1995 cohort, typically a factor of 4 to 10 times greater than that observed during the previous 15 years. When the first of these cohorts reached maturity in 1998, the spawning stock biomass expanded rapidly and the landings from the fishery nearly doubled from one year to the next $(0.64 \mathrm{Mt}$ in $1997,1.13 \mathrm{Mt}$ in 1998). The fishery continued to grow into the early 2000 s on the back of the strong year classes, and in 2004 landings reached $2.4 \mathrm{Mt}$, an increase of $400 \%$ in just 7 years. At this point, blue whiting was the largest fishery in the North Atlantic, ahead of herring, and the third largest marine capture fishery in the world (FAO, 2010). The subsequent decline of the fishery has, however, proved to be equally dramatic. Year class strengths from the 2005-2009 cohorts were comparable to, or even lower than, those prior to 1995 (ICES, 2013). The 2010-2012 cohorts are then apparently above average size. The extremely large fishery could not be sustained under these conditions of reduced productivity and rapid reductions in allowable catch followed. Landings were reduced by $75 \%$ in the space of 5 years.

\subsection{Bluefin tuna}

Bluefin tuna have historically migrated into the Norwegian and North seas, preying on the high concentrations of pelagic fish in this area during summer (MacKenzie and Myers, 2007; Mather et al., 1995). While they were in this region they were targeted by fishing vessels from several nations. The fishery developed in the 1920s-1940s, peaked in the 1950s and declined in the mid-late 1960s before ending in the mid-1970s. The species has since then been rarely seen and has not supported commercial or recreational fisheries. Reasons for the disappearance are unclear, but probably due to a combination of fishing and climatic and ecosystem factors (Fromentin, 2009; Tiews, 1978).

\subsection{Objectives}

Here we provide data on the spatial distribution of herring and blue whiting in the northeastern Atlantic that have been compiled by research vessels operated by several nations in the region. For NSS herring, data from the IESNS (international ecosystem survey in the Nordic Seas) survey in May in the Nordic Seas are presented (period: 2004-2012). Furthermore, data from three surveys are presented here for blue whiting: the IESNS survey in May in the Nordic Seas (period: 2004-2012), the French pelagic survey (PELGAS; period: 2000-2012) and the demersal bottom trawl surveys (EVHOE; period: 1997-2011). We have also compiled and presented a long time series of the commercial catches of bluefin tuna in this region resolved by different spatial regions and countries (period: 1906-2010). These data will help with studies into understanding the causes of fluctuations in abundance and distribution of these species and contribute to the wider objectives of a large European Union project (EURO-BASIN) investigating how climate variability and fisheries affect food webs and biogeochemical fluxes in the off-shelf regions of the northeastern Atlantic Ocean. Additional brief backgrounds of the species biology and fisheries are given in the Methods section. The survey and catch data reported here have been submitted to the PANGAEA website.

\section{Methods}

\subsection{Data sources and geographic region of coverage}

The survey and catch data described here cover a wide area of the northeastern Atlantic. The region is divided into smaller units for fishery and ecosystem management purposes by ICES (International Council for the Exploration of the Sea) (Figs. 3 and 4). The historical data on NSS herring and blue whiting in the northeastern Atlantic originate from various national and international surveys aimed at mapping the major distribution and estimating abundances and demographic structure of these large pelagic planktivorous fish species (e.g. ICES, 2009, 2011). The vast majority of data on NSS 


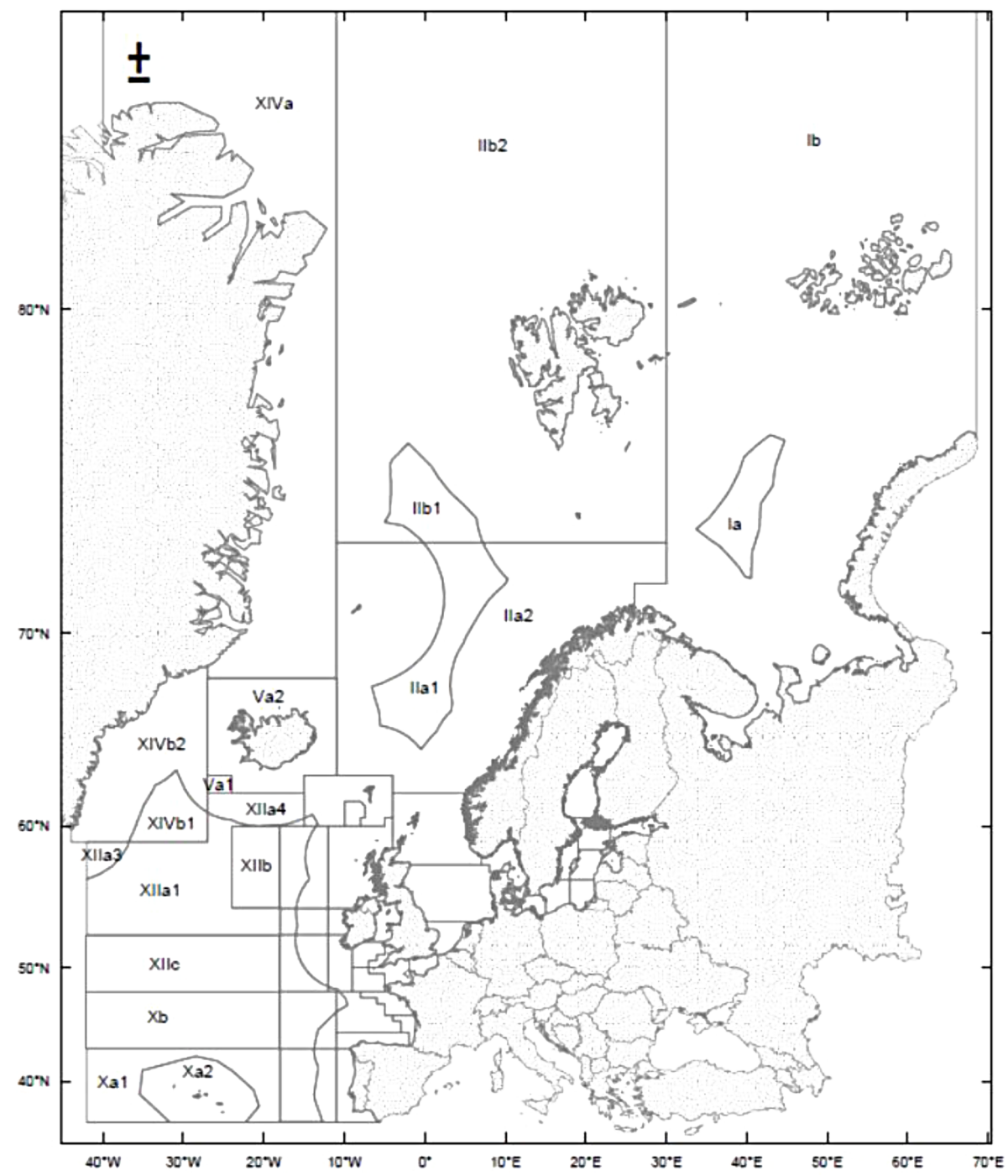

Figure 3. Locations of ICES fishery management areas in the northeastern Atlantic Ocean.

herring come from the annual IESNS survey carried out in May-June in the Norwegian Sea (ICES, 2013). Overall, historical and present data on blue whiting are primarily from the Norwegian Sea from 1997 to 2011, the annual international blue whiting survey carried out on the spawning grounds to the west of the British Isles in March-April 20042011 (ICES, 2011), and the nursery grounds in the Bay of Biscay and Celtic Sea in 1987-2012.

\subsection{The international ecosystem survey in the Nordic Seas (IESNS)}

The objective of the IESNS survey is to study the abundance and distribution of pelagic fish in the Nordic Seas, where the main focus has been on the NSS herring in relation to environmental and ecological conditions. A detailed description of the surveys can be found in survey reports (ICES, 2009) and a survey manual (ICES, 2014). The surveys were nor- mally carried out in late April to early June by five vessels, one from a European Union country, and the others from the Faroe Islands, Iceland, Norway and Russia. The surveys covered the Norwegian Sea and adjacent waters with parallel east-west transects at $40-60 \mathrm{nmi}$ (nautical miles) intervals, starting from south and heading towards north, and were carried out during $24 \mathrm{~h}$ each day. Trawl hauls were performed on acoustic registrations as needed in order to get information on species and length compositions with varying types and size of pelagic trawls. The catches were then sorted and weighed; fish were identified to species level, when possible, and other taxa to higher taxonomic levels. Normally a subsample of 50-100 herring and blue whiting were sexed, aged, and measured for length and weight, and their maturity status was estimated using established methods. An additional sample of 50-250 fish was measured for length. 


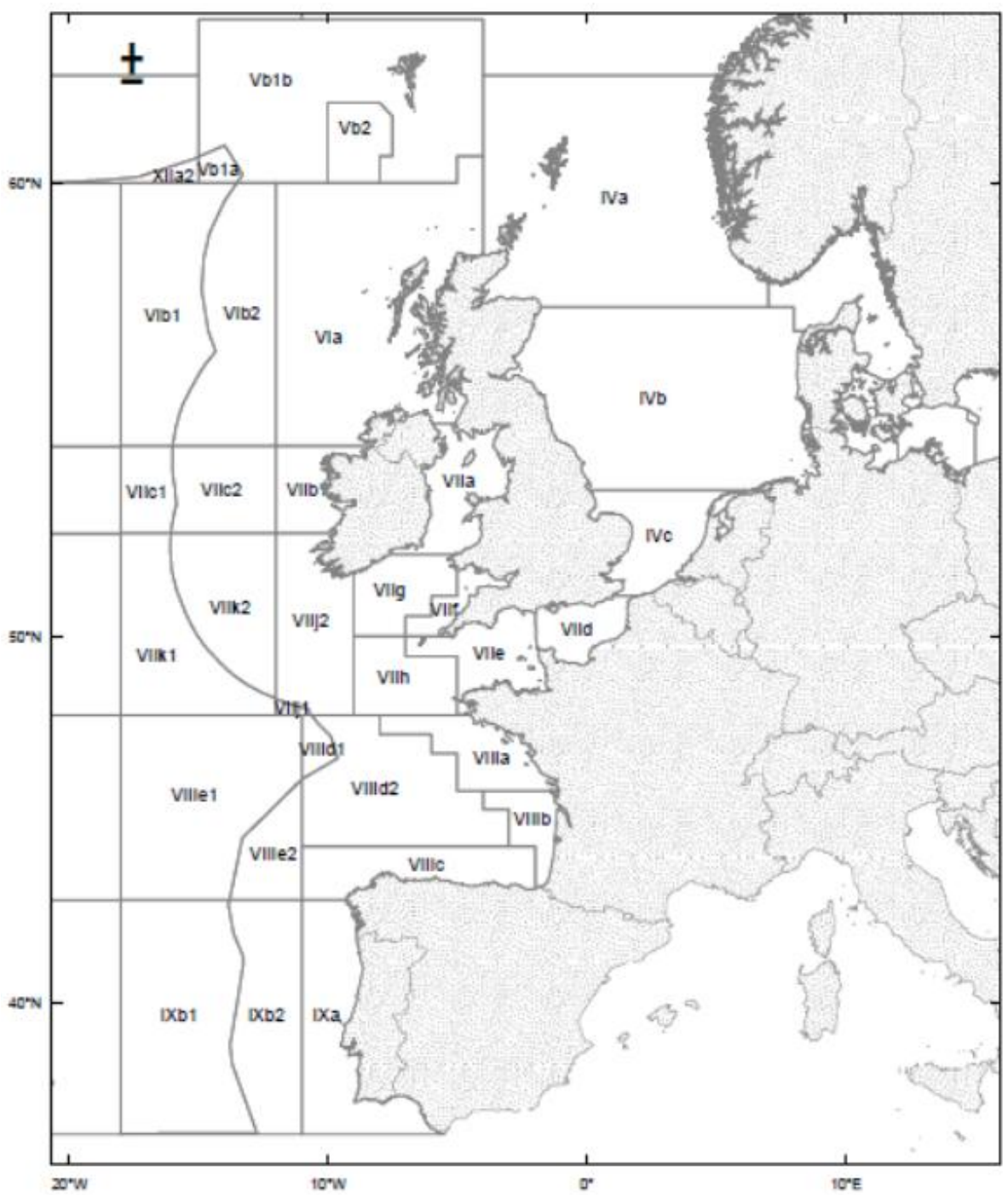

Figure 4. Locations of ICES fishery management areas on the northern European shelf-shelf-break region.

Acoustic estimates of herring and blue whiting abundance were obtained during the surveys. This was carried out by visual scrutiny of the echogram and using post-processing software (Knudsen, 1990; Korneliussen, 2004). This process involved collecting continuous acoustic recordings of fish using calibrated echo integration systems with $38 \mathrm{kHz}$ as the primary frequency. The echograms were analysed at a threshold of $-70 \mathrm{~dB}$. The scrutinised echo traces were integrated over the water column and the allocation of NASC (nautical area-scattering coefficient, $\mathrm{m}^{2} \mathrm{nmi}^{-2}$ ) (MacLennan et al., 2002) values to herring, blue whiting and other acoustic targets were based on the composition of the trawl catches and the appearance of echo recordings in a standardised way. To estimate the abundance, the allocated NASC values were averaged for ICES rectangles $\left(0.5^{\circ}\right.$ latitude by $1^{\circ}$ longitude). For each statistical rectangle, the unit area density of fish in number per square nautical mile $\left(\mathrm{Nnmi}^{-2}\right)$ was calculated using standard equations (Toresen et al., 1998). Traditionally the following target strength (TS) functions have been used:

Blue whiting: $\mathrm{TS}=21.8 \log (L)-72.8 \mathrm{~dB}$

Herring: TS $=20.0 \log (L)-71.9 \mathrm{~dB}$.

Note that, in 2012, the TS function was changed for blue whiting in all the main acoustic surveys within ICES (TS $=20 \log (L)-65.2 \mathrm{~dB}$ ) (ICES, 2011; Pedersen et al., 2011), but the abundance estimates in the PANGAEA database are based on the previously used function. To estimate the total abundance of fish, the unit area abundance for each statistical square was multiplied by the number of square nautical miles in each statistical rectangle and then summed for all the statistical rectangles within defined subareas and over the total area. Biomass was calculated by multiplying abundance in numbers by the average weight of the fish in each statistical rectangle then summing all rectangles 
within defined subareas and over the total area. The Norwegian BEAM software (Totland and Godø, 2001) was used to make estimates of total biomass and numbers of individuals by age and length in the whole survey area and within different subareas.

\subsection{The pelagic survey in the Bay of Biscay (PELGAS)}

Acoustic surveys were carried out every year in the Bay of Biscay in May from 2000 to 2012 (except 2001) onboard the research vessel Thalassa, which is equipped with a Simrad EK60 echo sounder operating at five frequencies $(18,38$, 70,120 and $200 \mathrm{kHz} ; 7^{\circ}$ beam angle at $-3 \mathrm{~dB}$ and $1.024 \mathrm{~ms}$ pulse length for all frequencies) at $6 \mathrm{~m}$ depth on the fixed vessel keel. Only the data collected at $38 \mathrm{kHz}$ were used here. The survey protocol for acoustic data collection has been stable since 2000. Systematic parallel transects (12 nmi distance) perpendicular to the French coast were carried out. The survey covered the continental shelf from $20 \mathrm{~m}$ depth to the shelf break about $200 \mathrm{~m}$ (in certain years more offshore). Acoustic data were only collected during daytime. During night the pelagic target species are usually dispersed and found close to the sea surface, and therefore they "disappear" in the blind layer of the echo sounder, which extends between the surface and $8 \mathrm{~m}$ depth. The calibration method has been stable over time.

Acoustic data were acquired with the Movies+ and Hermes software and archived in the international hydroacoustic data format (HAC) with a $-100 \mathrm{~dB}$ threshold applied. The identification of species and size classes comprising fish echo traces heavily depends on identification via trawl hauls performed by R/V Thalassa using a pelagic trawl (two doors; headline: $76 \mathrm{~m}$; foot rope: $70 \mathrm{~m}$ ). Echograms were scrutinised in real time and trawl hauls were performed as often as possible. The criteria for performing an identification haul included observation of numerous fish echotraces over several elementary distance sampling units (EDSUs) or of very dense fish echotraces in one EDSU, changes in the echotrace characteristics (morphology, density or position in the water column), and observation of an echotrace type fished on previous transects but never fished on the current transect.

The scrutinised echo traces were integrated over the water column by EDSU, providing NASC values. For deriving biomass and abundance estimates, acoustic energies were converted by applying catch ratios, length distributions and weighted by abundance of fish in the area surrounding haul. Further information on the survey and the data analysis methods can be found in Doray et al. (2010).

The objective of the PELGAS survey is to study the abundance and distribution of pelagic fish in the Bay of Biscay. The main target species of the survey are anchovy and sardine, but sprat, horse mackerel, mackerel and blue whiting are also covered. The identification of species and size classes comprising fish echotraces heavily depends on iden-

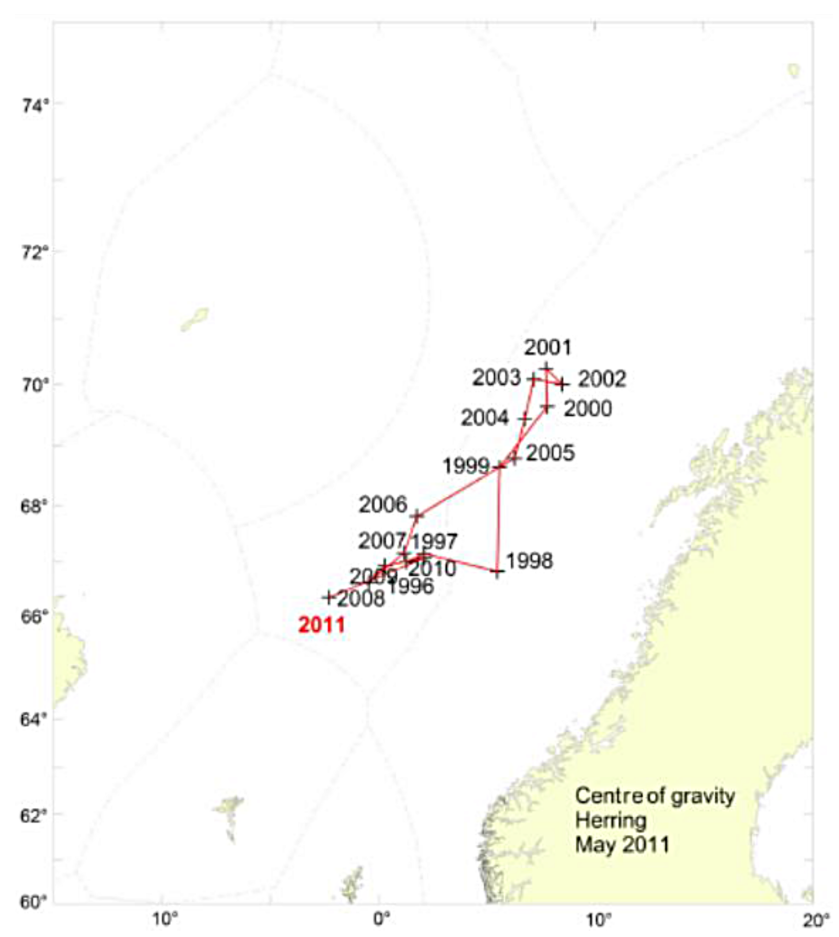

Figure 5. Centre of gravity of Norwegian spring-spawning (NSS) herring during the period 1996-2011 derived from acoustic data.

tification via trawl hauls performed by R/V Thalassa using the pelagic trawl (Doray et al., 2010).

\subsection{The Bay of Biscay and Celtic Sea bottom trawl survey (EVHOE)}

The EVHOE survey has been conducted onboard R/V Thalassa annually in autumn since 1987 in the Bay of Biscay and since 1997 in the Celtic Sea. The vessel was changed in 1997, but this did not impact the catchability of blue whiting (Pelletier, 1998). Between 50 and 100 stations are trawled with a grande ouverture verticale (GOV) bottom trawl according to a stratified random design based on bottom depth and latitude. The catch is identified to species level and individually measured. Further details on the survey protocol can be found online at https://datras.ices.dk/Documents/ Manuals/EVHOEManual.doc.

\subsection{Bluefin tuna catch data in northern European waters (ICES areas II-VII)}

Bluefin tuna catch data were extracted from the ICES catch databases for the time periods 1906-1949 and 1950-2010. The catch database versions used in this report were those available on the ICES website (http://www.ices.dk/marine-data/dataset-collections/Pages/ Fish-catch-and-stock-assessment.aspx) and downloaded on 21 January 2014. The data in the ICES catch databases 

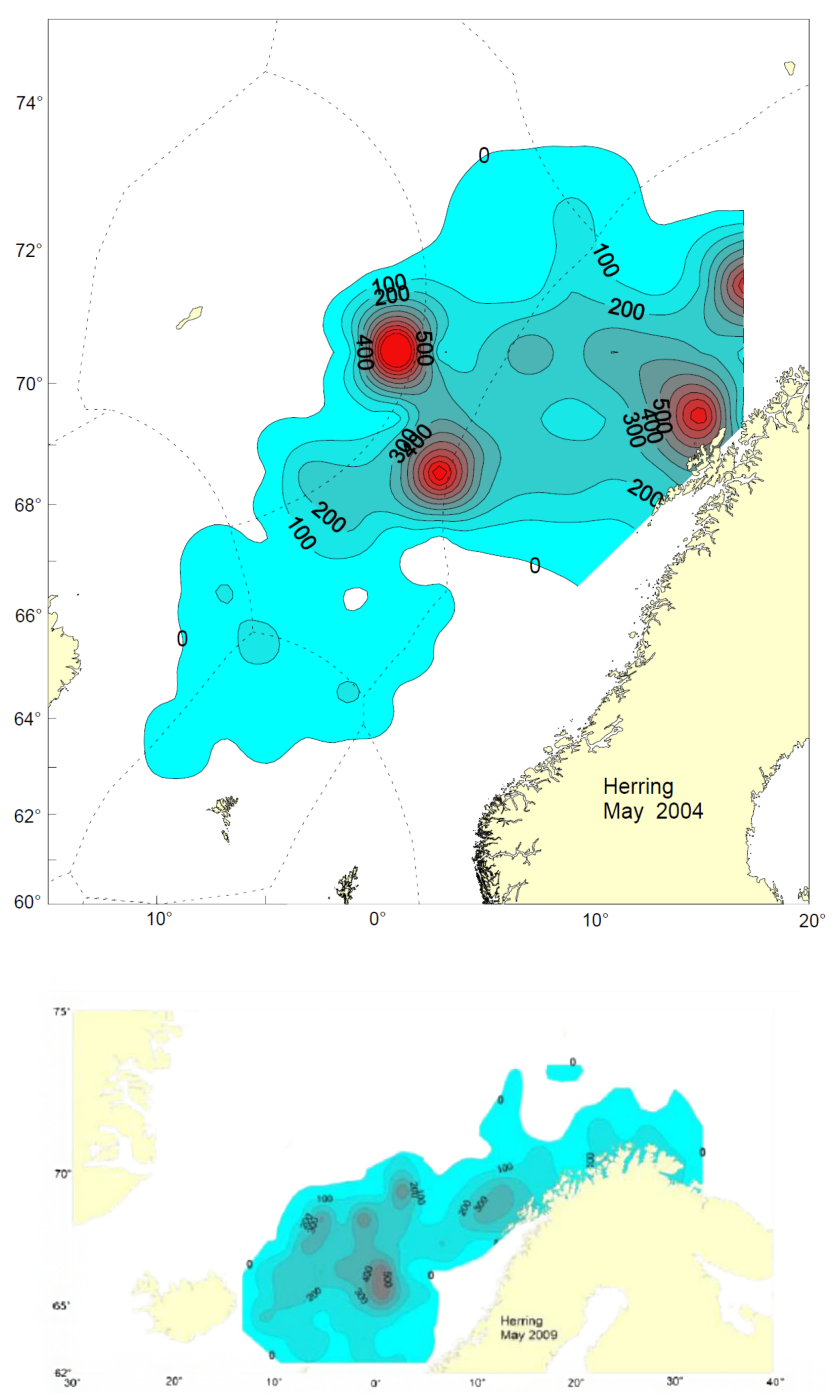

Figure 6. Distribution of NSS herring as measured during the IESNS survey in April-June 2004 (upper) and 2009 (lower) in terms of NASC values based on combined $5 \mathrm{nmi}$ values. From ICES (2004) and ICES (2009).

are derived from ICES Bulletin Statistiques; these data are annual statistical reports containing fishery data for northeastern Atlantic countries (Lassen et al., 2012). The data contained in those reports have been entered by ICES into the existing catch database. The data contained in the ICES catch database are resolved by species, year, country and sea region (known as ICES areas). For this report, we were most interested in the sea areas north of the Bay of Biscay, because this was the former summer foraging habitat until its disappearance in the 1970s and because catches in this region have undergone large fluctuations (see above) whose reasons remain unclear (Tiews, 1978; Mather et al., 1995; MacKenzie and Myers, 2007; Fromentin, 2009). We extracted data by year, country and region and made time series plots of the data to illustrate and compare temporal-
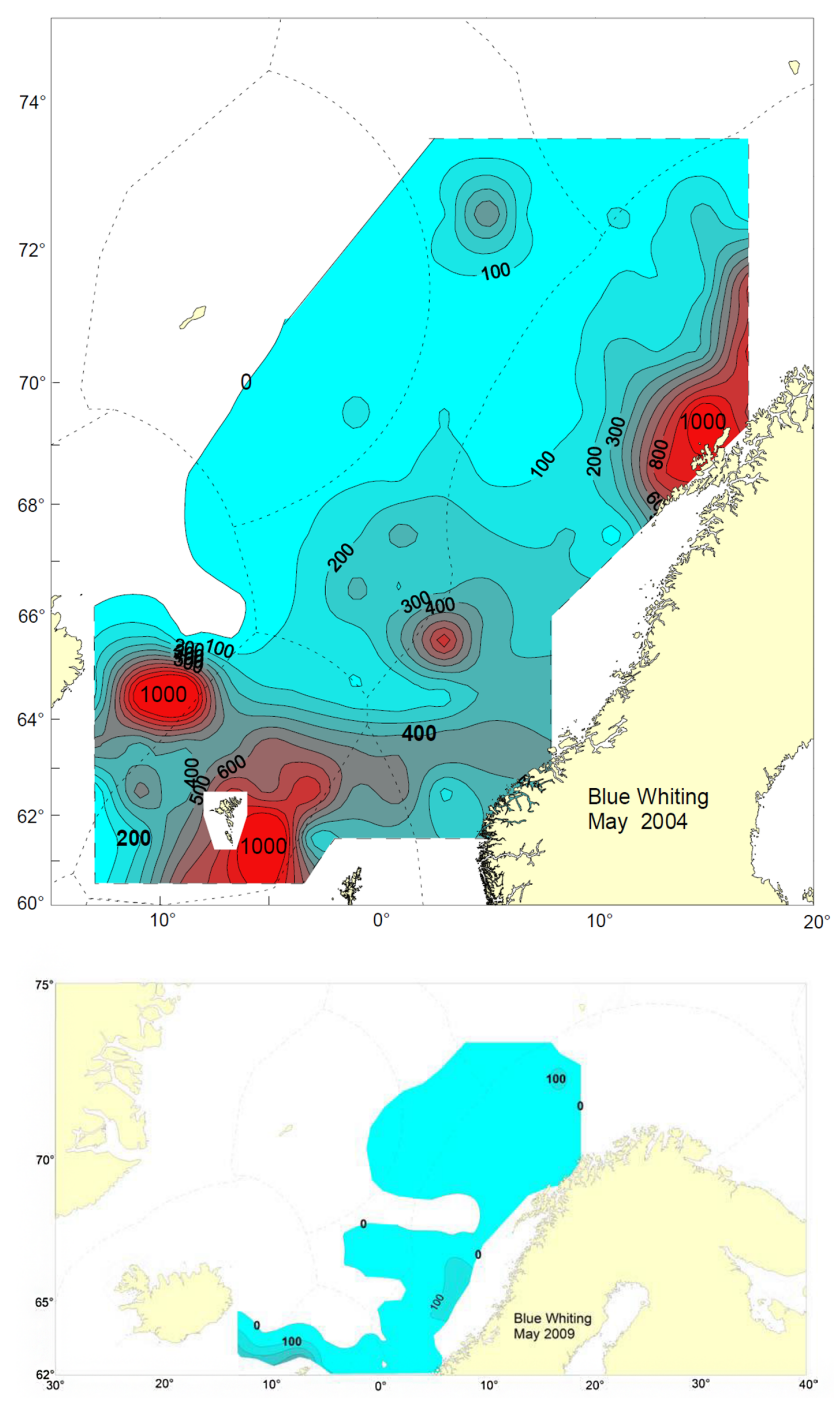

Figure 7. Distribution of blue whiting as measured during the IESNS in April-June 2004 (upper) and 2009 (lower) in terms of NASC values based on combined $5 \mathrm{nmi}$ values. From ICES (2004) and ICES (2009).

spatial trends and to identify which countries and/or regions had the largest catches.

We are also aware of some historical catch data which are not presently included in the ICES catch databases; these data have been identified in various fishery reports, museum records and scientific literature (MacKenzie and Myers, 2007), and are included in the database described here and available at the PANGAEA website. The data sources not included in the ICES catch database are identified with notes in the online data files.

The ICES areas considered are only part of the entire spatial domain over which the bluefin tuna fishery is managed, which covers the North Atlantic east of $45^{\circ}$ longitude and includes the Mediterranean and Black seas (ICCAT, 2012). Catches for these areas (i.e. northeastern Atlantic and 

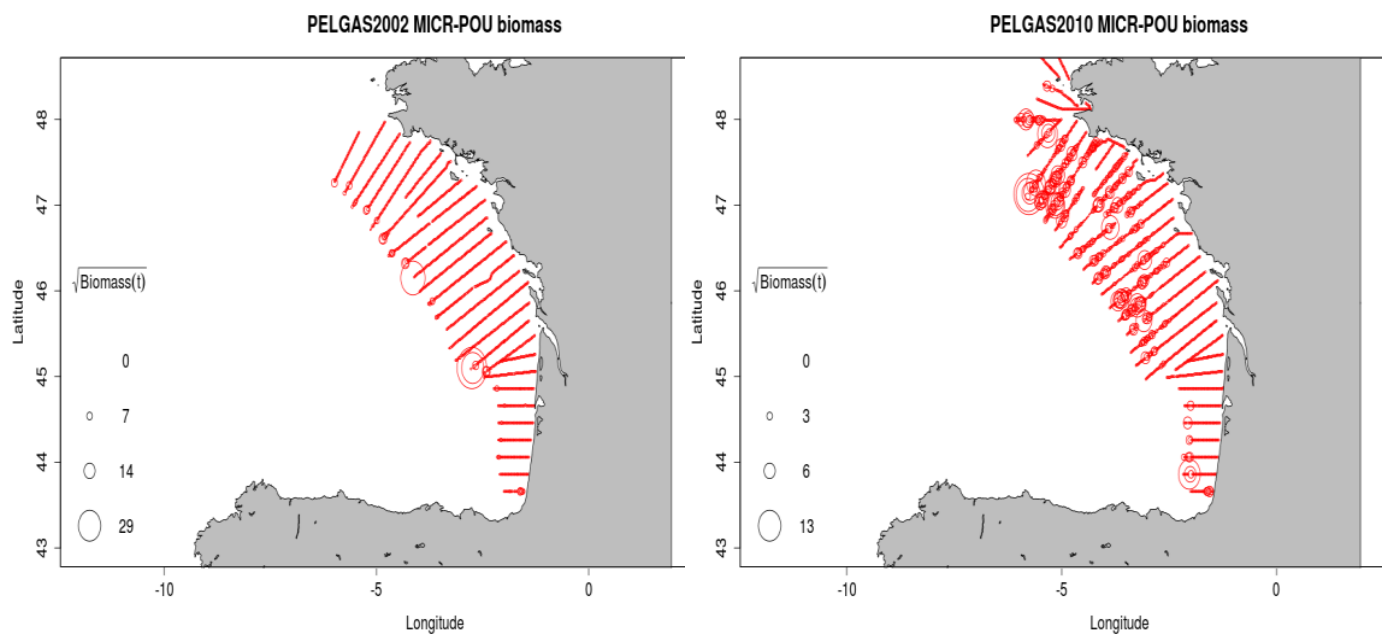

Figure 8. Blue whiting biomass estimates by EDSU from the PELGAS survey in 2002 (typical year, left) and 2010 (high biomass, right).

Mediterranean, including the Black Sea) are available from the International Commission for the Conservation of Atlantic Tunas (ICCAT), which is the agency responsible for management of bluefin tuna in the Atlantic and Mediterranean. We extracted and plotted the ICCAT catch data (total international landings) to enable comparison of the total international landings in the entire stock management area with the ICES data for the northern region. In principle, the catch data reported to ICES should be the same as those reported to ICCAT, but in some instances there may be some minor differences (Lassen et al., 2012), which are not considered further here.

\section{Results and discussion}

\subsection{Spatially explicit estimates of stock sizes, structure and biomass of NSS herring}

The centre of gravity for adult NSS herring shifted substantially from 1996 to 2011 (Fig. 5). From 1996 to 2003 the centre of gravity moved north/northeast by almost $4^{\circ}$ latitude. This represents a distance of $445 \mathrm{~km}$. From 2003 to 2011 a similar shift of $4^{\circ}$ latitude $(445 \mathrm{~km})$ in centre of gravity in the opposite direction towards south/southwest was evident, even though the survey coverage has remained rather stationary during this time (Utne et al., 2012). Maps of herring distribution and aggregation patterns, primarily from the international May survey from 1995 to 2011 are provided below based on acoustic estimates (NASC values) in forms of mean $5 \mathrm{nmi}$ values (Fig. 6).

NSS herring has changed its distribution and migration pattern substantially during the last decades in terms of spawning, feeding and overwintering areas (Fig. 1). Data on herring distribution and aggregation patterns from the IESNS survey from 2004 to 2012, are provided in PANGAEA. Examples of the data on herring distribution from this survey are shown in Fig. 6. For a more comprehensive review of the distribution of NSS herring, see Utne et al. (2012). There are various sources of uncertainty related to acoustic estimates for pelagic fish stocks. For NSS herring, inadequate coverage of the distribution area and active vessel avoidance by the herring are the two most important factors contributing to uncertainty in the acoustic abundance estimate (Løland et al., 2007).

\subsection{Spatially explicit estimates of stock sizes, structure and biomass of blue whiting}

The blue whiting SSB has fluctuated widely over the last three decades. Examples of the spatial distribution of the stock during the IESNS in May are shown in Fig. 7. In 2004 there are some high-density areas outside northern Norway and further south between the Shetland and Faroe islands and Iceland. In 2009, on the other hand, the stock size is much lower and consequently no comparable high-density areas are seen, and the stock is less widespread than in 2004.

\subsection{Spatial blue whiting estimates in the Bay of Biscay}

Spatial blue whiting biomass estimates in the Bay of Biscay for two contrasting years are shown in Fig. 8. The year 2002 was a typical year with little blue whiting biomass in the water column on the shelf, while in 2010 blue whiting was found in high abundance on the continental shelf. It should be noted that, as the survey is targeting anchovy and sardine, the transect lines end in general where schools of blue whiting are encountered. As adult blue whiting are distributed along the shelf edge further offshore, the PELGAS surveys do not cover the full distribution of this species in the Bay of Biscay. Hence it is difficult to distinguish a situation where blue whiting are more spread-out over the continental shelf because of favourable environmental conditions from a situation where 


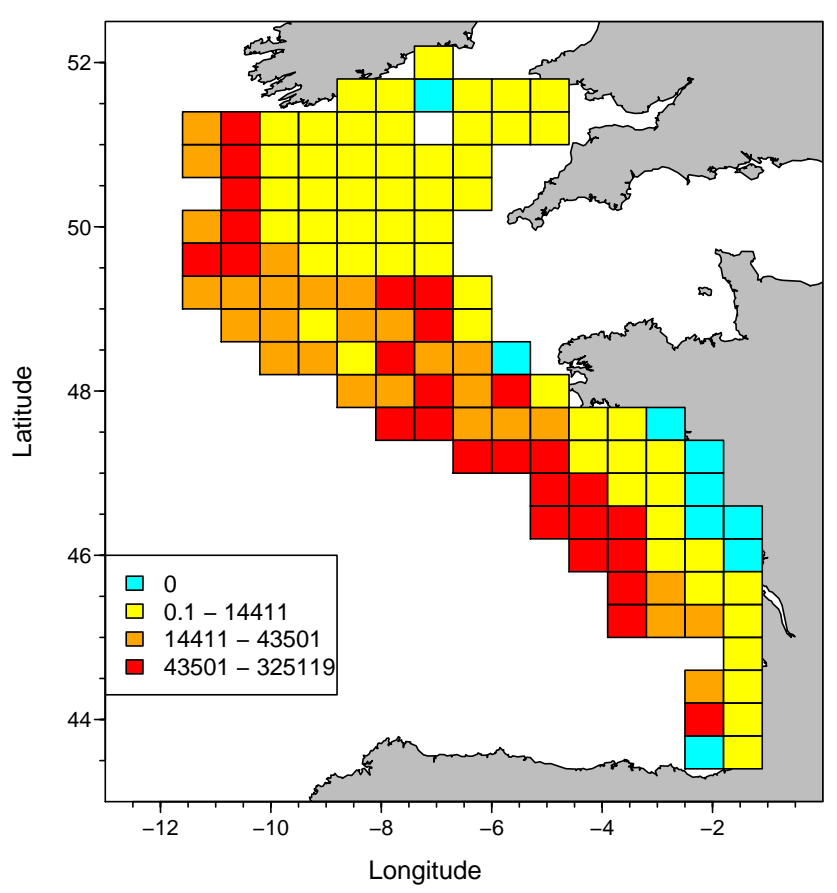

Figure 9. Average density (numbers per $\mathrm{km}^{2}$ ) of blue whiting during autumn in the period 1997-2011 in the EVHOE survey.

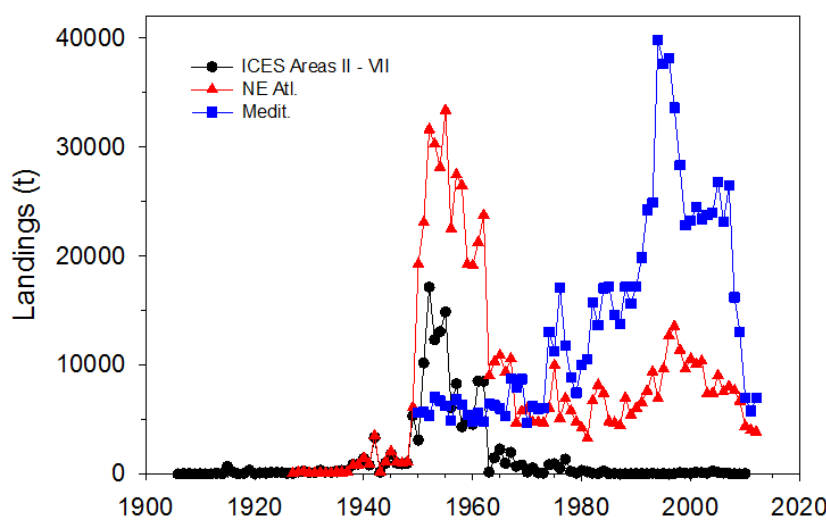

Figure 10. Temporal variability in reported catches of bluefin tuna, Thunnus thynnus, in different geographic areas. ICES areas IIVII correspond approximately to the Norwegian Sea south to the Celtic Sea and continental shelf west of Ireland and the UK (see Fig. 3). NE Atlantic includes the entire northeastern Atlantic and the Mediterranean Sea. Data sources include ICES catch databases (versions downloaded 21 January 2014) and other historical sources - see PANGAEA link for details.

spreading is caused by higher densities, or a combination of both.

The gridded average distribution of blue whiting across the years 1997-2011 is shown in Fig. 9. This map of the demersal part of the blue whiting stock, primarily made up of young of the year, shows that they are distributed along the

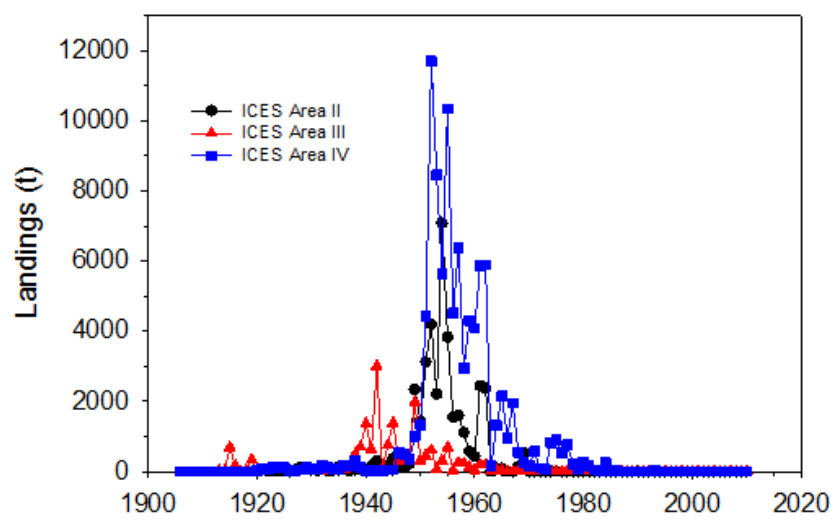

Figure 11. Temporal variability in reported catches of bluefin tuna, Thunnus thynnus, in different geographic areas. Areas II, III and IV represent approximately the Norwegian Sea, Skagerrak-KattegatBelt Sea-Øresund, and North Sea, respectively (see Fig. 4). Data sources include ICES catch databases (versions downloaded 21 January 2014) and other historical sources - see PANGAEA link for details.

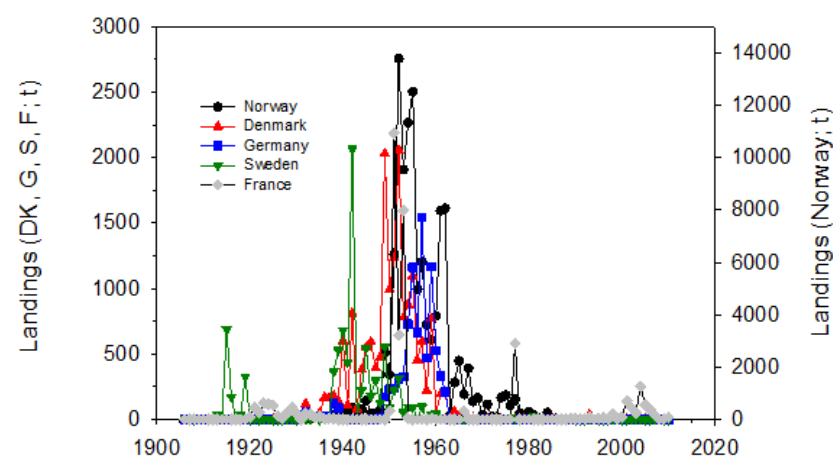

Figure 12. Temporal variability in reported catches of bluefin tuna, Thunnus thynnus, in ICES areas II-VII, by the countries with largest proportions of reported landings. Note that the Norwegian data on the right axis have a different scaling from the other countries. Most (96\%) landings occurred in areas II-IV. Data sources include ICES catch databases (versions downloaded 21 January 2014) and other historical sources - see PANGAEA link for details.

outer parts of shelf edge of the Bay of Biscay and Celtic Sea, similar to the pelagic adult part of the population in Fig. 8.

\subsection{Bluefin tuna catches - temporal, spatial and national distributions}

The ICES catch database (version 21 January 2014) for the areas I-VII first reports bluefin tuna data from 1931. Landings in this region were first reported to ICES by Germany for region IV (North Sea). Landings increased in the subsequent two decades, and additional nations (e.g. Denmark, Norway, Sweden) reported catches from other areas (e.g. Norwegian Sea, Skagerrak-Kattegat-Belt Sea-Øresund; Figs. 10-12). 


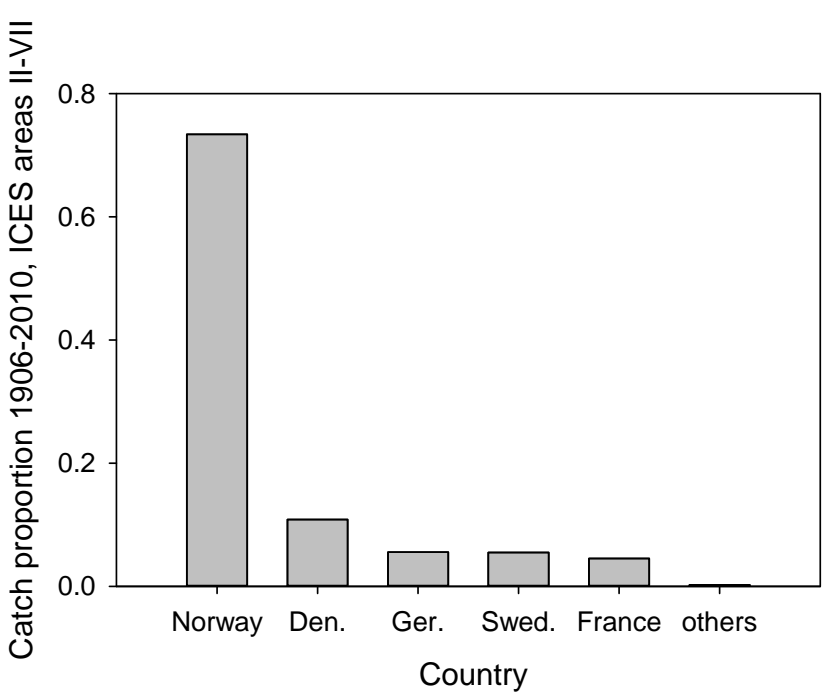

Figure 13. Proportion of total landings in ICES areas II-VII during 1906-2010. Data sources include ICES catch databases (versions downloaded 21 January 2014) and other historical sources - see PANGAEA link for details.

There is a notable omission of data from the version of the ICES catch database downloaded for this work. The data omitted are those from Norway. These data are, however, present in the original ICES Bulletins Statistiques and have been reported earlier in the literature (e.g. MacKenzie and Myers, 2007), and they are also included in the ICCAT database. The omitted landings are substantial because Norway had the largest catches of all countries in the region considered in this report until the fishery in this area declined in the mid-1960s to early 1970s. Moreover, Norway was the first country in this region to report its landings to ICES (starting in 1927; ICES, 1903-1972). The Norwegian landings which are in the ICES (1903-1972), but which are omitted from the ICES catch database, are those for 19271949 for areas II, III and IV.

Aside from the omission of early officially reported Norwegian landings, there are additional landings by Norway (Tangen, 1999) and a few other countries from the early decades of the 20th century which are not included in the ICES (1903-1972) or the present version of the ICES catch database. The earliest bluefin tuna catches noted (1907) were those by a French herring boat fishing at Dogger Bank in the southern North Sea. Several more years of French tuna catches in this area are available in French fishery reports (Statistiques de Pêches Maritimes; MacKenzie and Myers, 2007). Norwegian, Swedish and Danish fishermen also caught bluefin tuna in the Norwegian Sea and SkagerrakKattegat in the 1910s-1920s, and thus before these governments began reporting the landings to ICES (Fig. 12). In comparison with available catch data from ICCAT, the ICES data compilation presented here covers a longer time period and has higher spatial resolution (e.g. to regional sea level); however its geographic range is limited to waters of northern Europe, whereas the ICCAT database contains data from countries of southern Europe, including the Mediterranean Sea. A summary of historical bluefin tuna catches in the northwestern European waters with maps of catch locations is presented in LeGall (1927).

The vast majority of the catches $(96 \%$ by weight in the whole time period 1906-2010) were taken in areas II-IV, and the rest were in areas VI-VII. Norway, Denmark, Germany, Sweden and France were responsible for $99.8 \%$ of the total reported landings during 1906-2010; Norway's share was largest (73\%), followed by Denmark (11\%, Fig. 13).

Acknowledgements. We thank Øyvind Tangen for preparing IESNS data on NSS herring and blue whiting, and acknowledge all the people who went to sea and collected these valuable observations. We thank all countries which have provided data to ICES and ICCAT, as well as both organisations for maintaining catch databases. Paul J. B. Hart and David Miller are acknowledged for valuable comments on a previous version of the paper. This work received funding from the European Union Seventh Framework Programme project EURO-BASIN (ENV.2010.2.2.1-1) under grant agreement no. 264933.

Edited by: G. Melvin

\section{References}

Devold, F.: The life history of the Atlanto-Scandian herring, Rapports et Procès-Verbaux des Réunions du Conseil International pour l'Exploration de la Mer, 154, 98-108, 1963.

Doray, M., Mahevas, S., and Trenkel, V. M.: Estimating gear efficiency in a combined acoustic and trawl survey, with reference to the spatial distribution of demersal fish, Ices J. Mar. Sci., 67, 668-676, 2010.

Dragesund, O.: Distribution, abundance and mortality of young and adolescent Norwegian spring spawning herring (Clupea harengus Linne) in relation to subsequent year class strength, Fiskeridirektoratets Skrifter Serie Havundersøkelser, 15, 451556, 1970.

Dragesund, O., Hamre, J., and Ulltang, Ø.: Biology and population dynamics of Norwegian spring-spawning herring, Rapp. Proc. Verb. Réun. Cons. Int. l'Explor. Mer, 177, 43-71, 1980.

Dragesund, O., Johannessen, A., and Ulltang, Ø.: Variation in migration and abundance of Norwegian spring spawning herring (Clupea harengus L.), Sarsia, 82, 97-105, 1997.

FAO: Statistics and Information Service of the Fisheries and Aquaculture Department, FAO yearbook. Fishery and Aquaculture Statistics 2008, Rome, Italia, 72 p., 2010.

Fernö, A., Pitcher, T. J., Melle, W., Nøttestad, L., Mackinson, S., Hollingworth, C., and Misund, O. A.: The challenge of the herring in the Norwegian Sea: Making optimal collective spatial decisions, Sarsia, 83, 149-167, 1998.

Fridriksson, Á.: Norðurlandssíldin, Rit Fiskideildar, 1, 1-338, 1944.

Fromentin, J. M.: Lessons from the past: investigating historical data from bluefin tuna fisheries, Fish and Fish, 10, 197-216, 2009. 
Hilborn, R. and Branch, T. A.: Does catch reflect abundance? No, it is misleading, Nature, 494, 303-306, 2013.

Holst, J. C., Dragesund, O., Hamre, J., Misund, O. A., and Østvedt, O. J.: Fifty years of herring migrations in the Norwegian Sea, ICES Marine Science Symposia, 215, 352-360, 2002.

ICCAT: Report of the 2012 Atlantic bluefin tuna stock assessment session, Madrid, Spain, 4-11 September, Madrid, Spain, ICCAT, Report no. SCI-033/2012, 1 p, 2012.

ICES: ICES Bulletin Statistique des Pêches Maritimes (ICES Annual Bulletin of Marine Fishery Statistics), 1903-1972.

ICES: Report of the Planning Group on Northeast Atlantic Pelagic Ecosystem Surveys (PGNAPES), 24-27 August 2004 Murmansk, Russia, ICES CM 2004/D:07, 58 pp., 2004.

ICES: Report of the Planning Group on Northeast Atlantic Pelagic Ecosystem Surveys (PGNAPES), 18-21 August 2009, Tórshavn, Faroe Islands, ICES CM 2009/RMC:06, 139 pp., 2009.

ICES: Report of the Working Group on Northeast Atlantic Pelagic Ecosystems Surveys (WGNAPES), 16-19 August 2011, Kaliningrad, Russian Federation, ICES CM 2011/SSGESST:16, 193 pp., 2011.

ICES: Report of the Working Group on Widely Distributed Stocks (WGWIDE), ICES CM 2013/ACOM:15, 947 pp., 2013.

ICES: Manual for International Pelagic Surveys (IPS), Working Document to the Working Group of International Pelagic Surveys (WGIPS), 20-24 January 2014, ICES Headquarters, Copenhagen, ICES CM 2014/SSGESS:01, 358 pp., 2014.

Jakobsson, J. and Østvedt, O. J.: A review of joint investigations on the distribution of herring in the Norwegian and Iceland Seas 1950-1970, Rit Fiskideildar, 16, 209-238, 1999.

Knudsen, H. P.: The Bergen echo integrator - an introduction, J. Conseil, 47, 167-174, 1990.

Korneliussen, R. J.: The Bergen echo integrator post-processing system, with focus on recent improvements, Fish. Res., 68, 159169, 2004.

Lassen, H., Cross, D., and Christiansen, E.: One hundred years of catch statistics for the Northeast Atlantic, ICES Coop. Res. Rep. No. 311, 2012.

Le Gall, J.: Contribution 'a l'étude de la biologie du Thon Rouge (Thunnus thynnus L.). Sur la présence de Thons Rouges en Mer du Nord et dans l'Atlantique Nord-Est, J. Conseil, 2, 309-331, 1927.

Løland, A., Aldrin, M., Ona, E., Hjellvik, V., and Holst, J. C.: Estimating and decomposing total uncertainty for survey-based abundance estimates of Norwegian spring-spawning herring, Ices J. Mar. Sci., 64, 1302-1312, 2007.

MacKenzie, B. R. and Myers, R. A.: The development of the northern European fishery for north Atlantic bluefin tuna (Thunnus thynnus) during 1900-1950, Fish. Res. (Amsterdam), 87, 229239, doi:10.1016/j.fishres.2007.01.013, 2007.

MacLennan, D. N., Fernandes, P. G., and Dalen, J.: A consistent approach to definitions and symbols in fisheries acoustics, Ices J. Mar. Sci., 59, 365-369, 2002.

Mather, F. J., Mason, J. M., and Jones, A. C.: Historical document: life history and fisheries of Atlantic bluefin tuna, NOAA Technical Memorandum NMFS-SEFSC, 370, 1-165, 1995.
Monstad, T.: Blue whiting, in: The Norwegian Sea ecosystem, edited by: Skjoldal, H. R., Tapir Academic Press, Trondheim, 2004.

Pauly, D.: Does catch reflect abundance? Yes, it is a crucial signal, Nature, 494, 303-305, 2013.

Pedersen, T.: Tunfiskeriet fra Skagen (English: The Skagen tuna fishery), Vendsyssel Årbog, 1997, 83-102, 1997.

Pedersen, G., Godo, O. R., Ona, E., and Macaulay, G. J.: A revised target strength-length estimate for blue whiting (Micromesistius poutassou): implications for biomass estimates, Ices J. Mar. Sci., 68, 2222-2228, 2011.

Pelletier, D.: Intercalibration of research survey vessels in fisheries: a review and an application, Can. J. Fish. Aquat. Sci., 55, 2672 2690, 1998.

Pinnegar, J. K., Goñi, N., Trenkel, V. M., Arrizabalaga, H., Melle, W., Keating, J., and Óskarsson, G.: A new compilation of stomach content data for commercially important pelagic fish species in the northeast Atlantic, Earth Syst. Sci. Data, 7, 19-28, doi:10.5194/essd-7-19-2015, 2015.

Prokopchuk, I. and Sentyabov, E.: Diets of herring, mackerel, and blue whiting in the Norwegian Sea in relation to Calanus finmarchicus distribution and temperature conditions, Ices J. Mar. Sci., 63, 117-127, 2006.

Røttingen, I.: A review of variability in the distribution and abundance of Norwegian spring spawning herring and Barents Sea capelin, Polar Res., 8, 33-42, 1990.

Slotte, A. and Skaret, G.: Norwegian spring-spawning herring, p. 2-6 in: Life-cycle spatial patterns of small pelagic fish in the Northeast Atlantic, Editor Pierre Petitgas, ICES Coop. Res. Rep. No. 306, 2010.

Tangen, M.: Størjefisket på vestlandet (The bluefin tuna in the west country), Eide Publisher, Bergen, Norway, 1999.

Tiews, K.: On the disappearance of bluefin tuna in the North Sea and its ecological implications for herring and mackerel, Rapp. Proc. Verb. Réun. Cons. Int. l'Explor. Mer, 172, 301-309, 1978.

Toresen, R. and Østvedt, O. J.: Variation in abundance of Norwegian spring-spawning herring (Clupea harengus, Clupeidae) throughout the 20th century and the influence of climatic conditions, Fish Fish., 1, 231-256, 2000.

Toresen, R., Gjøsæter, H., and de Barros, P.: The acoustic method as used in the abundance estimation of capelin (Mallotus villosus Muller) and herring (Clupea harengus Linne) in the Barents Sea, Fish. Res., 34, 27-37, 1998.

Totland, A. and Godø, O. R.: BEAM: an interactive GIS application for acoustic abundance estimation, in: Proceedings of the 1st International Symposium on Geographic Information Systems (GIS) in Fishery Science, edited by: Nishida, T., Kailola, P. J., Hollingworth, C. E.,, Seattle, Washington, USA, 2-4 March 1999, pp. 195-201, 2001.

Utne, K. R., Huse, G., Ottersen, G., Holst, J. C., Zabavnikov, V., Jacobsen, J. A., Oskarsson, G. J., and Nøttestad, L.: Horizontal distribution and overlap of planktivorous fish stocks in the Norwegian Sea during summers 1995-2006, Mar. Biol. Res., 8, 420-441, 2012. 